\title{
Study on Efficiency of Biocontrol Agents for the Management of Rice Root- Knot Nematode, Meloidogyne graminicola in Paddy (Oryza sativa)
}

\author{
T. Senthilkumar* \\ Department of Plant Protection, Anbil Dharmalingam Agricultural College and Research \\ Institute, Tiruchirappalli - 620009, Tamil Nadu, India \\ *Corresponding author
}

\section{A B S T R A C T}

\begin{tabular}{|l|}
\hline Ke y w or d $\mathbf{s}$ \\
$\begin{array}{l}\text { Meloidogyne } \\
\text { graminicola, } \text { Paddy } \\
\text { (Oryza sativa) }\end{array}$ \\
\hline Article Info \\
\hline $\begin{array}{l}\text { Accepted: } \\
17 \text { July } 2018 \\
\text { Available Online: } \\
10 \text { August } 2018\end{array}$ \\
\hline
\end{tabular}

\section{Introduction}

The rice root knot nematode Meloidogyne graminicola is an endomic nematode pest of rice, causes serious damage in nurseries and upland rice (Prot et al., 1994). Jonathan and Padmanathan (2001) reported the nematode incidence in rice nurseries of Cauvery delta areas in Tamil Nadu. This root knot nematode has also been subsequently found to occur in main fields of irrigated rice in other parts of Tamil Nadu and cause yield loss 16-80 per cent. Generally various study were conducted to management of the root knot nematode in different crops. So far very limited research work has been made on the biological control of $M$. graminicola on rice. Therefore present experiment was conducted on rice variety TRY 3 for sustainable management of rice root knot nematode $M$. graminicola using biocontrol agents along with organic manures.

\section{Materials and Methods}

Nursery experiments were carried out on rice variety TRY3 with a plot (20 cents) nematode infested sick field during samba season (201416). Paddy seeds were surface sterilized with mercuric chloride $(0.05 \%)$ and sown through broadcasting after seed treatment with bioncontrol agents Pseudomonas fluorescens ( $10 \mathrm{~g} / \mathrm{kg}$ of seed, soil application of $P$. fluorescens@2.5kg/ha, combined application of $P$. fluorescens (Seed treatment $10 \mathrm{~g} / \mathrm{kg}$ of 
seed + soil application $2.5 \mathrm{~kg} / \mathrm{ha}$ ), farm yard manure (1 tonne/20 cent), chemical nematicides carbofuran 3G @33kg/ha and untreated control. All the treatments were replicated four times in Randomized Block Design.

The nursery experiments were terminated at 30 days after sowing and observation on plant growth parameters were made. The soil and root samples were collected for estimation of nematode population in soil and root gall index (Taylor and Sasser, 1978) and recorded. The data recorded were pooled and analyzed statistically.

\section{Results and Discussion}

Results revealed that all the treatments were significantly increased the plant growth parameters compared to untreated control. Seed treatment with bioncontrol agents $P$. fluorescens $(10 \mathrm{~g} / \mathrm{kg}$ of seed), soil application of $P$. fluorescens $(2.5 \mathrm{~kg} / \mathrm{ha})$, combined application of $P$. fluorescens (seed and soil application), farm yard manure (1 tonne/20 cent), chemical nematicides carbofuran $3 \mathrm{G}$
$(33 \mathrm{~kg} / \mathrm{ha})$ were found to be effective for the management of rice root knot nematode, $M$. graminicola. Among the treatment the chemical nematicide carbofuran 3G @ $33 \mathrm{~kg} / \mathrm{ha}$ and combined application of $P$. fluorescens (seed and soil application) minimizing the root gall index (3) and enhancing the growth of rice seedlings in terms of shoot weight $1.40 \mathrm{~g}$ and $2.60 \mathrm{~g}$ and root weight $1.20 \mathrm{~g}$ and $2.25 \mathrm{~g}$ respectively followed by soil application of $P$. fluorescens, seed treatment with $P$. fluorescens, Farm yard manure recorded reduction in rice root-knot nematode. Earlier research had shown that the chemical nematicides carbofuran $3 \mathrm{G}$ was effective in the management of plant parasitic nematodes in different crops, particularly against M. graminicola (Krishna Prasad and Rao, 1984). The results of the present study also fall in line with the report of Ramakrishna et al., (1988), where P. fluorescens was found to be effective against Hirchmanniella gracilis in rice. Further, the use of farmyard manure @ 1 ton/20 cent had also been reported to be effective, but the degree of nematode control was greater than the effect of carbofuran $3 \mathrm{G}$ in the management of $M$. graminicola (Table 1).

Table.1 Efficacy of biocontrol agents on rice root knot nematode Meloidogyne graminicola management in rice

\begin{tabular}{|c|c|c|c|c|c|c|}
\hline Treatment & $\begin{array}{l}\text { Shoot } \\
\text { length } \\
\text { (cm) }\end{array}$ & $\begin{array}{l}\text { Shoot } \\
\text { weight } \\
\text { (g) }\end{array}$ & $\begin{array}{l}\text { Root } \\
\text { length } \\
(\mathrm{cm})\end{array}$ & $\begin{array}{l}\text { Root } \\
\text { weight } \\
\text { (g) }\end{array}$ & $\begin{array}{l}\text { Nematode } \\
\text { population } \\
\text { (200 ce soil) }\end{array}$ & $\begin{array}{l}\text { Gall } \\
\text { index }\end{array}$ \\
\hline $\begin{array}{l}\text { T1- Seed treatment with Pseudomonas } \\
\text { fluorescens @ } 10 \mathrm{~g} / \mathrm{kg} \text { of seed }\end{array}$ & 23.00 & 1.65 & 6.25 & 1.55 & 89 & 3 \\
\hline $\begin{array}{l}\text { T2 - Soil application of Pseudomonas } \\
\text { fluorescens @ 2.5kg/ha }\end{array}$ & 22.50 & 1.90 & 7.50 & 1.75 & 84 & 4 \\
\hline $\begin{array}{l}\text { T3 - Combined Application of } \\
\text { Pseudomonas fluorescens (10g/kg of } \\
\text { seed) + Soil application (@2.5kg/ha) }\end{array}$ & 26.50 & 2.60 & 8.50 & 2.25 & 73 & 3 \\
\hline T4 - Farm yard manure (1tonne/20 cent) & 21.50 & 1.45 & 5.75 & 1.55 & 97 & 4 \\
\hline T5 - Carbofuran 3G @33kg/ha & 20.00 & 1.40 & 6.00 & 1.20 & 113 & 3 \\
\hline \multirow[t]{2}{*}{ T6 - Untreated control } & 16.50 & 1.00 & 3.50 & 0.90 & 142 & 5 \\
\hline & 2.15 & 0.14 & 0.15 & 0.65 & 14.72 & - \\
\hline
\end{tabular}

*Pooled analysis of two season data 
The present study, concluded that the seed treatment $(10 \mathrm{~g} / \mathrm{kg}$ of seed) along with soil application of biocontrol agents $P$. fluorescens $(2.5 \mathrm{~kg} / \mathrm{ha})$ can be effective for the management of rice root knot nematode M. graminicola in nursery.

\section{References}

Jonathan, E.I., and Padmanathan, N.R. (2001). TNAU (Tamil Nadu Agricultural University) Newsletter 23: 4.

Krishna Prasad, K.S. and Rao, Y.S. (1984). Indian Journal of Nematology 14: 125127.
Prot, J.C., Villiannera, L.M. and Gergon, E.B. (1994). Fundamental and Applied Nematology 7: 445-454.

Ramakrishnan, S., Sivakumar, C.V. and Poornima, K. (1998). Journal of Biological Control 12: 135-147.

Taylor, A.L. and Sasser, J.N. (1987). Biology, identification and control of root-knot nematodes (Meloidogyne spp.) Coop. Pub. Department of Plant Pathology. North Caroline State University and U.S. Agency International Development Releigh, NC, USA, $111 \mathrm{pp}$.

\section{How to cite this article:}

Senthilkumar, T. 2018. Study on Efficiency of Biocontrol Agents for the Management of Rice Root-Knot Nematode, Meloidogyne graminicola in Paddy (Oryza sativa). Int.J.Curr.Microbiol.App.Sci. 7(08): 3038-3040. doi: https://doi.org/10.20546/ijcmas.2018.708.323 